\title{
Buying power and human rights in the supply chain: legal options for socially responsible public procurement of electronic goods
}

\author{
Olga Martin-Ortega, Opi Outhwaite and William Rook \\ School of Law, University of Greenwich
}

\begin{abstract}
:
Several scandals involving well-known electronics brands have highlighted the exploitative and unsafe conditions under which many workers operate in the industry's long and complex supply chains. As large-scale consumers of electronic goods public buyers potentially hold significant leverage over the behaviour of their suppliers through their buying power. Consequently, public procurement has the potential to be a significant influence on these supply chains and ultimately the human rights of those working in them. This article critically assesses legal options for the promotion of social considerations in the supply chain, considering in particular the potential of the EU legal regime for public procurement as a tool for improving working conditions and human rights in the electronics industry supply chain.
\end{abstract}

Key words:

Human rights; labour rights, working conditions; supply chain; electronics industry; public procurement; due diligence; European Union 


\section{Buying power and human rights in the supply chain: legal options for socially responsible public procurement of electronic goods}

\section{Introduction}

The electronics industry supply chain is particularly complex, with many companies involved in the manufacturing process and most of them far removed from the end user. In 2010 a number of workers committed suicide in the Foxconn factory in Shenzhen, China, allegedly due to the harsh working conditions they were subjected to and hundreds of others threatened threaded-to do so. ${ }^{1}$ The Taiwanese company Foxconn supplies for a number of well-known electronics brands. Since then media attention has brought to light numerous other examples of worker's rights abuses and exposed the exploitative and unsafe conditions under which many workers in the supply chain operate in the electronics industry supply chain. ${ }^{2}$. As large-scale consumers of electronic products, public bodies can, through their buying power, hold significant leverage over the behaviour of their suppliers. Consequently, public procurement has the potential to be a significant influence on these supply chains. However, whilst the inclusion of environmental considerations in public procurement is relatively advanced, international and European regulation has been more restrictive in terms of social procurement and human rights have not been part of this legal regime. The recently adopted reforms of the European Union (EU) public procurement regime have, however, opened the door further for social considerations to be included in the procurement process.

This article critically assesses legal options for the promotion of human rights in the supply chain, particularly the potential for the EU public procurement regime to be used as a tool for improving working conditions in the electronics industry. The article first discusses the nature of the electronics supply chain, considering its global reach and the recognised problems with working conditions and workers' rights violations. The second part analysiseses EU public procurement law and the extent to which social and supply chain considerations are permitted. This section reflects on both the prevailing rules and those that have been introduced in the 2014 reforms. Finally, the third section considers options for incorporating supply chain issues into the public procurement process. With a focus on overcoming existing legal challenges, this section considers how incorporating human rights and social criteria relevant to the supply chain might be pursued concentrating on contractual relationships and corporate due diligence.

\section{The electronics industry supply chain}

\subsection{The nature of the electronics supply chain}

The electronics industry supply chain extends from the extraction of raw materials to the manufacture and assembly of products at large factories contracted by global brands. The brand or 'lead firm' conceives of the product and initiates its production as well as carrying the product branding. In the electronics industry these firms are very high-value enterprises. Given that hardware producers are noted as seven out of the top ten most valuable brands in the world 
and, additionally, Apple Inc. has been named the world's most valuable company, ${ }^{3}$ electronic goods are the tangible and very visible output of a supply chain that generates significant profits for those firms. ${ }^{4}$

In common with other sectors operating in international markets the production of electronic goods often takes place in the context of a multi-level global supply chain. ${ }^{5}$ A single product may contain work carried out by several companies in multiple countries and global sourcing and relocation of factories is common. ${ }^{6}$ The lead firm frequently carries out little or no manufacturing or production itself and contracted suppliers (or 'contract manufacturers') are instead used by the brand. These suppliers may be large enterprises with many employees and multiple locations such as FoxxConn, Flextronics and Inventec. These companies assemble the products and may purchase components and assemble parts of the final product (such as circuit boards). The OECD reports that these companies are often large companies with operations in different countries, but have limited market power and are less likely (than the lead firms) to be based in developed countries. ${ }^{7}$

The contracted suppliers may carry out manufacturing themselves but they may, alternatively, work with subcontractors who manufacture specific components that form part of the final product. ${ }^{8}$ The factories that produce the components and finished electronic goods often employ vast numbers of people to work on their production lines. A significant proportion of this manufacturing takes place in China and East Asia. ${ }^{9}$ China is the largest producer of electronics goods worldwide, employing an estimated 7.6 million people in the industry but electronics factories are also present in many other (mostly low-income) jurisdictions, including Taiwan, Mexico, Malaysia, and the Philippines. ${ }^{10}$

Beyond manufacturing, there are a great many human rights considerations that affect other parts of the electronics supply chain, such as in the extraction, trade, processing, transportation of raw materials and recycling and waste management. This article focuses on the levels of the supply chain where products and components are manufactured and assembled and not on other stages. Similarly, while many issues in the broad field of human rights can be discussed in relation to global production systems, this article focuses specifically on the labour rights of workers in the supply chains.

\subsection{Labour rights and working conditions}

A number of difficulties with governance of global supply chains in general have been recognised. The lead firm is typically not in a contractual relationship with the employees of its suppliers or with subcontractors nor in turn do those suppliers assume equivalent responsibilities in relation to their own subcontractors. Consequently, where there is a failure to adhere to particular standards or to respect employees' rights, the failure has been the responsibility of the employer in that specific part of the supply chain, rather than the responsibility of the brand which commercialises the product.

In tandem with this separation of obligations and responsibilities along the supply chain, the industry=- having a global market with a reported worth upwards of USD \$3.2 trillion- ${ }^{11}$ is under significant consumer and investor pressure to innovate and to reduce the lead-times to bring new products to market. These demands create pressure on contracted suppliers to increase productivity and reduce costs. At the manufacturing level this has led to 
concerns about conditions for employees including inadequate working conditions and human rights violations. ${ }^{12}$ In recent times the manufacture of electronic goods has been subject to widespread media coverage highlighting poor working conditions in the supply chain and in extreme cases suicide of factory workers. ${ }^{13}$ Problems sometimes relate to a lack of enforcement with national laws but in other instances laws may be inadequate or absent. Further, some countries in which manufacturing takes place may not have signed core International Labour Organisation (ILO) Conventions. ${ }^{14}$

Reports into working conditions in the electronics industry supply chain consistently exposed deficiencies in the protection of workers' rights. Pressure to get products to market in a short time frame has been associated with the use of flexible labour. ${ }^{15}$ Reports highlight the use of contracted labour, which limits job security and often prevents employees from accruing benefits that would be available through permanent employment as well as preventing opportunities for advancement. ${ }^{16}$ Employment of student workers or employees on a probationary basis can also prevent employees benefiting from conditions and wages that would be available to permanent employees. ${ }^{17}$ Staff turnover may be high in factories, again preventing workers from deriving employment benefits. ${ }^{18}$ The use of migrant labour has also been as identified as a problem; ${ }^{19}$ these employees can be more vulnerable to the demands of employers and more willing to tolerate exploitative practices. ${ }^{20}$ Again they may be subject to precarious terms of employment and those commuting long distances have been found to live in poor quality, overcrowded accommodation in order to reduce their own expenditure. ${ }^{21}$ For 'local' workers accommodation can also be a problem, with similarly inadequate standards and overcrowding being reported in employee dormitories. ${ }^{22}$

Conditions in the factories themselves may also be poor. Strict rules for employees are reported - for instance, with inadequate time for rest or meal breaks - together with punitive sanctions for breaches of these rules. ${ }^{23}$ Health and safety is also an identified problem, including exposure to hazards, especially chemicals, along with other health problems among employees. ${ }^{24}$ For employees of all types wages may be inadequate and can be less than a living wage. ${ }^{25}$ Routine overtime and excessive working hours may be used both by employees as a means of making wages reach an adequate level and by employers to ensure that lead times are met. Forced overtime has been reported. ${ }^{26}$ For contract workers, deductions by agencies further reduce these wages. ${ }^{27}$ Discriminatory practices are a further area of concern. In some instances women have been favoured as employees because they attract lower wages, in others discrimination has been identified against pregnant women. ${ }^{28}$ Attempts to assert employment rights or improve conditions are difficult where there are barriers to association and representation or because participation in strikes or other action lead to punitive action from the employer. ${ }^{29}$

Although demand for electronic goods continues to grow, ${ }^{30}$ concern about the human rights of workers in the electronics supply chain is also growing. The increasing profile of these concerns along with additional pressure on corporations to recognise responsibilities throughout their supply chain ${ }^{31}$ point to a need for new and more effective responses to managing the electronics industry supply chain. In the electronics industry however consideration of labour and social criteria is reported to have emerged only recently. Sony, for instance, is identified as having published environmental reports since 1994 but it is only as of 2000 that some electronics companies have been looking at working conditions in their supply chains. ${ }^{32}$ Some industry initiatives have also emerged. The Electronic Industry Citizenship 
Coalition Code of Conduct (EICC Code) comprises members from the electronics industry who are encouraged to adopt and implement the Code. ${ }^{33}$ The EICC currently lists 84 members including many major brands and suppliers. ${ }^{34}$ The Code of Conduct 'provides guidance on five critical areas of CSR [corporate social responsibility] performance': Environment, Ethics, Health and Safety, Labour, Management System [sic] and is monitored through an auditing process. ${ }^{35}$ The Global e-Sustainability Initiative (GeSI) focuses on 'achieving integrated social and environmental sustainability through ICT [Information and Communications Technology]' and includes a programme to raise labour and environmental standards in the supply chain, from primary production (mineral extraction) to manufacture (i.e. of components). In collaboration with the EICC, GeSI develops common tools that aim to improve standards as well as reducing the resource burden and other barriers for companies seeking to raise standards in their supply chain. ${ }^{36}$ In 2014 a new independent monitoring organisation, Electronics Watch, was launched. Electronics Watch works specifically with public buyers to support their efforts for socially responsible public procurement of electronics goods. ${ }^{37}$ Despite these initiatives, reports by labour organisations have continued to identify the presence of conditions contrary to the asserted aims of these initiatives and limited knowledge, if any, of the existence of codes of conduct by employees. ${ }^{38}$

\section{Public Procurement as a tool for promoting human rights}

\subsection{The potential for public procurement to influence workers' rights in the electronics supply chain}

Public procurement offers a potentially valuable contribution to the search for strategies to improve workers' rights and working conditions in the electronics supply chain and stands out as means of creating market demand for responsibly manufactured goods. Certainly, more enlightened corporate social responsibility policies from international brands, greater legal protection for workers' rights in producing countries, and increased advocacy and civil society pressure are all powerful tools in this pursuit, but crucially public procurers are consumers of electronics goods, and their purchasing requirements are a significant influence on corporate profits and therefore a good incentive for companies to address workers' rights issues in their supply chain. As Howe notes, public procurement can simply provide sufficient economic leverage to overcome corporate resistance to act. ${ }^{39}$ At the same time, it can act as a regulatory tool both to increase compliance with existing labour laws and to overcome questions about the desirability and effectiveness of non-governmental regulation and corporate social responsibility (CSR) as a strategy for improving working conditions in the absence of state regulation. ${ }^{40}$ This section explores the conceptual possibilities for public procurement as a tool to address workers' rights in the electronics supply chain and then the practical scope to do so within the framework of EU rules.

Public procurement contracts worldwide are estimated to be worth one-thousandbillion euros annually. ${ }^{41}$ Governments in OECD member states spend on average $12 \%$ of their GDP on public procurement, ${ }^{42}$ rising to an average of $16 \%$ in the European Union (EU). ${ }^{43}$ Electronic goods comprise a significant portion of public purchases, are often high value items and are procured in high volumes. ${ }^{44}$ Given the buying power associated with public procurement contracts they also hold the potential for significant leverage in social and sustainability issues. ${ }^{45} \mathrm{~A}$ procurement regime in this context may be used to pursue so called horizontal or secondary policies related to social, including human rights or environmental 
aims. Here public procurement regulation represents a powerful legal instrument available to contracting authorities to ensure compliance with secondary or non-commercial goals. ${ }^{46}$

Socially responsible procurement is not itself a completely new proposition but the extent of its application remains limited. ${ }^{47}$ The pursuit of environmental objectives is comparatively well established and has seen relatively rapid development. The use of procurement to achieve human rights and social aims is less well established but it appears that, within the framework of the welfare state, governments since the 19th century have incorporated horizontal policies linked with domestic employment policies such as promoting local employment and manufacturing, stipulating that suppliers to public authorities meet equality and diversity criteria, and requiring payment of wages at established levels. ${ }^{48} \mathrm{It}$ is only recently however that the potential for public procurement to be applied to promote human rights, and in particular workers' rights in the global supply chain is being explored.

The Sweatfree Purchasing Consortium is a leading example of innovation with respect to the possible positive impacts of public procurement. ${ }^{49}$ Established in 2010 the Consortium acts as membership organisation for US public entities to assist them to implement sweatshopfree purchasing practices. ${ }^{50}$ The initiative is based upon recognition of the economic influence of public procurement as a means of influencing working conditions in the supply chain. The focus to date has been on the apparel industry but may over time extend to other products. ${ }^{51}$ The model established by the Consortium is based on the member public entities developing a sweatfree procurement policy, including a code of conduct to be used at all stages of the procurement process, i.e the evaluation and post award stages._- The Consortium guides public buyers on the content of this code, which should include requirements that their suppliers comply with all national and regional legal requirements in the areas where they operate as well as with the core ILO Conventions. Furthermore, it suggests public buyers to consider setting standards for wages beyond the legally required minimum wage in the country of production, such as the provision of “_an adequate living wage.'”- The model also calls for independent monitoring of the supply chain. The expectation is that contractors should know and disclose the location of factories in their supply chains and should know and report on the extent of compliance with the buyer code of conduct. Member entities may require contractors to state that they and their subcontractors have the capacity to comply with the code of conduct through a declaration of compliance. With respect to enforcement, buyers are expected to recognise that suppliers cannot realistically certify compliance for operators along the supply chain and that non-compliance in the supply chain is common. An approach based on procedural requirements and having the right processes in place is therefore considered to be more effective than simply requiring immediate compliance. The Consortium model also provides for complaints to be made by workers to an independent monitor and for collaborative action between the parties to be taken to respond to violations. Although currently limited to a small number of states and cities, ${ }^{52}$ this approach clearly acts on the possibility for public procurement to be used as tool to address human rights issues in the supply chain.

The Sweatfree Purchasing Consortium notwithstanding, the use of public procurement in pursuit of social goals, is underdeveloped. Contributing to this has been an emphasis on 'value for money', narrowly defined, and the aim of promoting free trade and competition. Further, the use of procurement to promote labour standards extraterritorially, this is in jurisdictions beyond those of the public buyer raises questions of legal compatibility, legitimacy and sovereignty. ${ }^{53}$ 
To understand how social criteria, and particularly workers' rights and supply chain considerations might be included within the process of public procurement, it is necessary to consider the public procurement process in more detail. Once the public buyer has determined the goods to be procured they are obliged to establish the criteria on which tenders will be compared and evaluated and then the conditions under which the contract must be performed. These are the three key stages of the tender process. First, technical specifications are used to define the subject matter of the contract. ${ }^{54}$ Technical specifications are the required characteristics of the product or service tendered for and should be specified in the tender documents. Second, award criteria are used to determine the basis on which contracts are awarded, and again, should be made public before the contract has been awarded. They allow the public buyer to make comparisons between tenders and can be weighted, with points awarded based on the ability of the tenderer to meet each of the specified criteria. Finally, contract performance conditions can be used to establish conditions that must be performed by the successful bidder once the contract has been awarded. They should also be specified in the tender documents. Whilst conceptually these stages all allow for the incorporation of social considerations, in practice the overarching objectives and the detailed provisions of public procurement regulation in the EU mean that incorporation of social criteria into the public procurement process is restricted as will be explained in detail in the following section. Environmental and social policies have been on the EU agenda for over two decades ${ }^{55}$ but while EU public procurement rules have expressly permitted environmental requirements to be considered in different stages of the public procurement process, the same scope and legal certainty has not existed for social considerations. ${ }^{56}$

\subsection{The EU Framework for public procurement}

The underpinning purpose of public procurement regulation is to establish a fair system for providing goods and services to public authorities through the application of rules on transparency, non-discrimination, and fair competition. The main thrust of the international legal regime applicable to the procurement of goods and services by public bodies is to open up this potential market through the application of rules on transparency and competition. As a signatory of the World Trade Organisation (WTO), the EU and its member states have to comply with the Plurilateral Agreement on Government Procurement (GPA). ${ }^{57}$ The GPA, like other WTO Agreements, aims to increase international trade and eliminate or reduce discriminatory trade rules and the protection of national markets. The GPA encompasses key principles of the wider WTO framework including national treatment and non-discrimination. This, broadly, means that national rules should not treat foreign goods or services (here concerning procurement) less favourably than those produced domestically and that goods or services cannot be discriminated against based on the country of ownership, production or origin. ${ }^{58}$ Consequently, parties to the GPA cannot discriminate in favour of domestic producers/suppliers and any detailed rules adopted should not usually provide an advantage to given countries, or the domestic market.

In the framework of the EU, all public sector authorities, whatever the procurement, are subject to the Treaty on the Functioning of the European Union (TFEU), most significantly in relation to rules on equal treatment, freedom of establishment, and freedom to provide 
services. This means that at the very least contracting entities must act transparently and must treat all bidding parties equally, proportionately, and without discrimination.

The legal framework for public procurement had remained unmodified for a decade, with the main instruments being the Public Sector Directive (2004/18) and the Utilities Directive (2004/17). ${ }^{59}$ A revised legislative package for modernisation of EU public procurement was approved by the European Parliament on 15 January 2014 and adopted by the Council on 11 February 2014. The new Directives came into force in April 2014 and must be implemented by member states within two years of that date. The reformed public procurement Directive (2014/24/EU) ${ }^{60}$ aims to modernise public procurement rules including through simplification and increased flexibility, improved market access and a reduction in the 'missed opportunities for society' including through additional provisions for social objectives. ${ }^{61}$ For the purposes of this article the Directive can be seen as developing the procurement framework rather than introducing radical changes.

EU legislation only applies to public contracts above the specified economic threshold ${ }^{62}$ therefore national legislators are free to regulate public procedures for lower amounts in different ways to those specified in the Directives, as long as they comply with TFEU provisions. ${ }^{63}$ Two basic principles apply to public procurement in the context of the EU: (i) obtaining value for money and (ii) acting fairly within European and national legislation. ${ }^{64}$ 'Value for money' is described as implying that contracting authorities have an obligation to safeguard taxpayers' interests by procuring goods and services in the most cost-effective way. Best value for money is not purely price sensitive, but rather it is price sensitive within the defined parameters of the goods or services required, which take into account factors such as quality, efficiency, effectiveness, and fitness for purpose, but may also include other factors, including environmental considerations. ${ }^{65}$ 'Acting fairly' means applying the principles of the internal market established in the TFEU and the Procurement Directives. Respecting the principles of non-discrimination, equal treatment, transparency and proportionality, contracting authorities must ensure equal access to the contract by operators from all EU countries and from countries with equivalent rights; not treat comparable situations differently and different situations in the same way, unless such treatment is objectively justified; advertise tender opportunities widely enough to ensure competition and proceed with transparency during the procurement decision-making process to preclude any risk of favouritism or arbitrariness, informing unsuccessful tenderers of the reasons for rejecting their tenders; and finally adopting measures in the procurement process that are appropriate to the objectives pursued and do not go beyond what is necessary to achieve them. ${ }^{66}$

These principles clearly restrict, in overall terms the considerations, with respect to 'horizontal policies' that can form part of the procurement process. The new Directive purports to enable better integration of social and environmental considerations into public procurement procedures. This is reflected throughout the preamble in which reference to the importance of integration of environmental, social and labour requirements into public procurement procedures is made (Recital 37), recognition is given to the potential use of labelling for works, supplies or services conforming with specific environmental, social or other characteristics (Recital 75) and the potential to incorporate social and environmental considerations into various stages of the procurement process and to ensure that international agreements and standards are respected (Recitals 97-105). These reforms respond to calls for fair trade and 
sustainability to take a more central role in the EU economy and to advances by the jurisprudence of the Court of Justice of the European Union. ${ }^{67}$

\subsubsection{Technical Specifications}

The process of defining the technical specifications would, in principle, be the first opportunity to incorporate supply chain considerations into the procurement contract. ${ }^{68}$. The characteristics of a product or service that must be identified within the procurement documents as technical specifications have remained largely the same in the new Directive. The technical specifications that are expressly permitted include: quality levels, environmental performance level, design for all requirements (including accessibility of disabled people) and conformity assessment performance, use of the product, safety or dimensions (including requirements relevant to the product as regards the name under which the product is sold), terminology, symbols, testing and test methods, packaging, marking and labelling, user instructions, production processes, conformity assessment procedures and climate change performance. ${ }^{69}$ These criteria could be formulated on their own or by reference to specific, national, European or international standards approved by a recognised standardising body. The definition of technical specifications does not explicitly recognise general social criteria nor does it make reference to minimum labour standards or other considerations relevant to the supply chain. Only a limited reference to social considerations is included, establishing that whenever possible technical specifications should be defined so as to take into account accessibility criteria for people with disability or design for all users.

The new rules appear to widen the potential use of technical specifications: under Article 42 technical specifications may refer to 'the specific process or method of production or provision of the requested works, supplies or services or to a specific process for another stage of its life cycle even where such factors do not form part of their material substance provided that they are linked to the subject-matter of the contract and proportionate to its value and its objectives' [emphasis added]. This requirement that technical specifications are restricted to the subject-matter of the contract presents however the main obstacle to including social considerations, and in particular those relating to the protection of workers' rights in the supply chain. Article 42(4) specifically excludes the possibility of referring to given production methods or processes as part of the technical specification unless it is 'justified by the subject-matter of the contract'. The term 'subject-matter' is not defined in Directive 2014/24, nor was it in the 2004 Directive, but this requirement clearly limits the availability of technical specifications to be used as a tool for promotion of human rights and other social considerations. The conditions of workers in the supply chain might not therefore be allowed to be included as part of the technical specifications of a product, even if it might be considered as part of the production process, because it does not appear to directly relate to the subjectmatter of the contract. ${ }^{70}$

Technical specifications can also be defined by reference to the use of labels. Whilst Directive 2004 restricted these to eco-labels, the new Directive opens this use wider, to include the use of social labels (Art. 43(1)). ${ }^{71}$ Art 43(2) refers to the situation where a label meets the requirements of Art 43(1) but also sets out further requirements, which are not linked to the subject-matter of the contract. In this case only the parts of the label that are linked 'to the subject-matter of the contract and are appropriate to define characteristics of this subjectmatter' may be included in the technical specification. The way that components are produced 
or the rights and working conditions of those producing them are unlikely to meet this subjectmatter requirement. The potential to include in the specification social labels referring to production processes and human rights standards further along the supply chain therefore appears to be excluded. ${ }^{72}$

In conclusion, although a general reference to the inclusion of social considerations is made in the new Directive, its application will be limited in practice given the restrictions discussed above. The inclusion of references to the production process and life-cycle of a product could have been an opportunity to include social considerations as part of the technical specifications, in particular the respect of labour rights and the consideration of working conditions in the supply chain, but this possibility is restrained by the need for technical specifications to relate to the subject matter of the contract.

\subsubsection{Award Criteria}

Award criteria are used to determine the basis on which contracts are awarded. Award criteria can be weighted, with points allocated based on the ability of the tenderer to meet each of the specified criteria. The procurement documents must specify each criteria and their weighting. The 2004 Directive limited the criteria under which contracting authorities could base the award of public contracts to either: (a) the most economically advantageous tender (from the point of view of the contracting authority) or, (b) the lowest price. ${ }^{73}$ The criteria to determine the most economically advantageous tender had to be linked to the subject matter of the public contract, and included, quality, price, technical merit, aesthetic and functional characteristics, running costs, cost-effectiveness, after-sales and technical assistance, delivery date and delivery period or periods of completion. Therefore under that regime the production process and considerations of working conditions during the manufacturing of the product were not elements to consider when establishing the most economically advantageous bid in awarding the contract.

The new Directive initially appears to take a less restrictive approach. Recital 97 in particular provides for broader use of award criteria (or contract performance conditions) 'with a view to the better integration of social and environmental considerations in the procurement procedures'. Recital 97 refers to the use of award criteria in respect of 'any stage in the life cycle' of the product (this might, for instance, include its manufacture), and including 'factors involved in the specific process of production [...] even where such factors do not form part of their material substance' (for instance manufacturing conditions). Nevertheless, the condition of a link with the subject matter of the contract remains. ${ }^{74}$ It correlates therefore that Recital 97 confirms that a general CSR requirement should not be attempted within the scope of the subject matter requirement, stipulating that: 'the condition of a link with the subject-matter of the contract excludes criteria and conditions relating to general corporate policy, which cannot be considered as a factor characterising the specific process of production or provision of the purchased works, supplies or services. Contracting authorities should hence not be allowed to require tenderers to have a certain corporate social or environmental responsibility policy in place.' Further, Recital 98 makes it clear that any social aspects of the production process to be included must relate to the goods that are to be provided under the contract.

More specific references to working conditions are made under Recital 99 although these appear to emphasise internal (member state) employment policies, specifically 'measures 
aiming at the protection of health of staff involved in the production process' and the 'favouring of social integration of disadvantaged persons'. Relevant criteria are suggested as, for example, 'the employment of long-term job-seekers, the implementation of training measures for the unemployed or young persons in the course of the performance of the contract to be awarded.' The reference to the health of the persons involved in the production process is directly relevant when questioning whether contracting authorities could include workers' rights and working conditions in the supply chain as part of the award criteria, as long as a connection could be made to long working hours, unhealthy and unsafe working environments, restriction of rest time, etc., to the health of the workers (directly involved in the production process). In this respect then, pertaining to the preamble, the Directive 2014/24 provides more opportunities for incorporating human rights and social criteria into the award phase.

In the new Directive, contracts are to be awarded simply to the most economically advantageous tender (and not on the basis of 'lowest price' as in the 2004 Directive). Article 67 sets out specific rules concerning award criteria. This provision provides that the most economically advantageous tender, from the point of view of the contracting authority, shall be identified on the basis of the price (or cost) using a cost-effectiveness approach and may include the best price-quality ratio 'which shall be assessed on the basis of criteria, including qualitative, environmental and/or social aspects, linked to the subject-matter of the public contract in question'. Again, subject-matter is not defined, but Article 67(3) provides that '[a]ward criteria shall be considered to be linked to the subject-matter of the public contract where they relate to the works, supplies or services to be provided under that contract in any respect and at any stage of their life cycle' including factors involved in the process of production or a specific process for another stage of their life cycle, even where such factors do not form part of their material substance. The potentially wide scope of the life cycle provision is therefore again restricted by the subject matter requirement. There may be greater scope to explore this in the award criteria phase because of the possibility of establishing a link between the life-cycle of the product and the subject-matter when determining costeffectiveness. However this would require that social criteria including respect for the rights of workers in the supply chain could be read into the meaning of subject-matter and that this could be factored into an assessment of the price-quality ratio in order to determine the most economically advantageous tender.

One of the rationales of the new Directive is to allow for strategic use of public procurement in response to new challenges. Among these are sanctioning violations of mandatory social, labour or environmental law as recognised in Recital 37. ${ }^{75}$ Recital 103 further states that rejection of abnormally low tenders should be mandatory where the contracting authority has established that the reason for the low price is because of noncompliance with EU or compatible national law in the fields of social, labour or environmental law. Article 69(3) confirms that 'contracting authorities shall reject the tender, where they have established that the tender is abnormally low because it does not comply with applicable obligations referred to in Article 18(2). These measures make significant reference to the importance of compliance with international and other law (albeit that relevant mandatory laws may not apply to some supply chain problems or in certain locations). However, the requirement that the authority establish that the tender is low because of this restricts their practical impact particularly where global supply chains are in question: the authority may have limited if any knowledge of the details of the supply chain much less the resources to satisfy this threshold. 
Overall, the new Directive does appear to open the door to inclusion of social considerations including human rights in award criteria but the general lack of references to the supply chain and the scope of social criteria is at the same time limiting. This means that it is likely that further guidance from the European Court of Justice will be needed to establish the parameters of these measures. The removal of references to lowest price as the basis for awarding the contract and the more widely defined terms for economically advantageous may help to shift the emphasis of the procurement process from a strictly 'bottom line' approach. The reference to subject-matter (and failure to adequately define that term) is again a limitation but in the context of award criteria - as compared with technical specifications - there appears to be greater scope to incorporate measures pertaining to the life cycle of the product, widely construed.

\subsubsection{Contract Performance Conditions}

Contracting authorities have been much freer to impose environmental and social considerations when negotiating conditions governing how the contract with the tenderer must be performed in comparison with the other phases of procurement. Since contract performance conditions apply after the contract has been awarded they do not impact the assessment of tenders and therefore are less likely to cause problems related to the principles of equal treatment and non-discrimination.

Directive 2004/18 provided that social considerations were allowed in contract performance conditions as long as they were not directly or indirectly discriminatory and were indicated in the contract notice. ${ }^{76}$ In its Preamble the Directive specifically listed conditions intended to favour onsite vocational training, the employment of people experiencing particular difficulty in achieving integration, the fight against unemployment or the protection of the environment. Overall, the 2004 Directive was restricted to domestic social considerations and specific reference to social considerations in the Preamble was not replicated in the Articles of the Directive. ${ }^{77}$

Directive 2014/24 goes further in incorporating social considerations. The references to social criteria in Recitals 97-99, discussed above, also apply to contract performance conditions. Contract performance conditions are permitted under Article 70 where related to the subject-matter of the contract within the broader meaning established in Art 67(3). ${ }^{78}$ Article 70 expressly states that those conditions may include 'economic, innovation-related, environmental, social or employment-related considerations'. Thus a wider and apparently more permissive rule than those applicable at earlier stages of the procurement process applies here.

Specifically relevant to the supply chain challenges are the use of subcontractors. Directive 2014/24 directly addresses such use. The 2004 Directive had provided that the contracting authority may ask or be required by a member state to ask the tenderer to indicate any share of the contract he may intend to subcontract. Maintaining this provision Directive 2014/24 (in Art 71(2)), it also provides in Art 71(1): 'observance of the obligations referred to in Article 18(2) by subcontractors is ensured through appropriate action by the competent national authorities acting within the scope of their responsibility and remit.' Art 18(2) establishes as a principle of procurement the position that member states shall take appropriate steps to ensure that in the performance of public contracts, economic operators comply with 
applicable obligations of social, environmental and labour law including those specified in Annex X which includes the core International Labour Organisation Conventions such as those addressing freedom of association, right to organise and collective bargaining; forced and child labour, discrimination and equal pay. ${ }^{79}$ Further, Art 71(6) provides: with the aim of avoiding breaches of Art 18(2), (a) 'where the national law of a member state provides for a mechanism of joint liability between subcontractors and the main contractor, the member state concerned shall ensure that the relevant rules are applied in compliance with the conditions set out in Article 18(2)' and (b) the contracting authorities may required to confirm whether there are grounds for exclusion of subcontractors pursuant to Art 57. In this case the economic operator may be required to replace the subcontractor. The question of subcontractors is also referred to in the preamble, which recognised that '[it] is important that observance by subcontractors of applicable obligations in the fields of environmental, social and labour law [..._-be ensured through appropriate actions by the competent national authorities within the scope of their responsibilities and remit, such as labour inspection agencies or environmental protection agencies' ${ }^{80}$ Reference is also made to the importance of transparency in the subcontracting chain but here the emphasis is specifically on the presence of employees within a domestic context.

Whilst these measures lack some detail they do go further than the 2004 Directive in placing a positive expectation on the member states to enable labour standards such as applicable ILO standards to be respected including by subcontractors. The measures of a Directive are addressed to the member states and primarily require action by the member states rather than public buyers. There is therefore the matter of implementation to consider before assessing the full outcome of the new provisions. Nevertheless, the measures in the new Directive appear clearly to envisage the incorporation of social criteria in contract performance conditions including those related to workers' rights and working conditions and more explicitly recognise the link between subcontracting (and therefore supply chains) and social and employment standards.

Overall, the new Directive has clearly taken up the challenge of incorporating social considerations into the public procurement regime. The specific scope for acting on this basis is sometimes less clear. Concerning technical specifications the options are still relatively restrictive. A number of changes have been made to the provisions on award criteria and the opportunity to incorporate social considerations has increased though it is not clear how supply chain matters may fall within this category. References to contract performance conditions may have gone further through direct reference to the need for compliance with listed international instruments including by subcontractors. One important limitation with the changes as a whole, with regards to the challenges of the electronics industry supply chain, is that, significant though the references to ILO standards are, these will currently only go part of the way to addressing problems in the chain. Some issues, such as freedom of association, collective bargaining and combating child labour, fall within the scope of Annex X, incorporating as it does the fundamental ILO Conventions. But others, such as payment of a 'living wage' and protection against excessive working hours, do not. In addition, although vague or widely framed wording allows for interpretation of the rules on social criteria, the European Commission has issued guidance which seems to emphasise that the social provisions are intended to pursue internal EU or member state objectives and/or where there is a clear link with the product or service (the subject matter condition) or the initial location of the contract and cannot be used as a general basis to require social responsibility. ${ }^{81}$ 
On the basis of the above analysis, the greatest remit for inclusion of terms affecting the supply chain lies in the contract performance stage. The imposition of performance conditions was previously (under the 2004 Directive) the most permissive of the procurement process and this does not appear to have been substantively altered for present purposes. References to the use of subcontractors, although again limited, and the general social considerations in Art 18, provide the least restrictive references to social criteria. Also, as mentioned, the imposition of contract performance conditions does not interfere with the evaluation of tenders and so is less likely to fall foul of rules on non-discrimination giving public buyers more freedom to incorporate such conditions.

\section{Using contract performance conditions to improve workers' rights in the electronics supply chain}

\subsection{Approaches to the use of contract performance conditions}

Although the incoming EU Directive does include more references to social criteria than its predecessor limitations clearly remain. Particular challenges posed by the supply chain, including the electronics supply chain, comprise the need for conditions to have extraterritorial reach; this is, to apply to countries along the supply chain, many of which are not EU member states. Conditions would also need to apply in the context of complex supply chain relationships in which there may be many parties and where the factories involved in that chain are often not in a contractual relationship with the public buyer and in some cases also not the contracting supplier. Equally, as businesses in the supply chain operate in multiple jurisdictions legal standards establishing protection for workers vary and may not be entirely clear for all those involved in the chain. Therefore, the practical means by which these supply chain issues can be tackled in the procurement process is far from clear. As discussed, the best opportunity to incorporate human rights and social considerations in the procurement process appears to be through the use of contract performance conditions. However, even in this phase of the procurement process applying contractual conditions to improve supply chain conditions is not straightforward. At a general level, difficulties arise because the public buyer is not in a contractual relationship with the subcontractors along the chain. Whilst the public buyer may agree conditions with the contracting supplier, without additional efforts the buyer has no role in ensuring that the desired conditions are adopted by the supplier in their contracts with subcontractors. A public buyer cannot impose requirements on parties with whom it is not in a contractual relationship and nor is it in a position to enforce or monitor conditions further along the supply chain. The effective use of contract performance conditions consequently will rely on finding ways of overcoming these limitations and ensuring that the desired standards or outcomes are incorporated along the chain. Consideration in the literature is, however, limited with regard to the ways in which contract performance conditions could in fact be used to achieve responsible supply chain objectives and what those conditions might be. This section seeks to further the analysis in this area by considering options for the use of specific contract performance conditions based on two different approaches (i) the use of contract terms throughout the supply chain and (ii) a due diligence approach which places emphasis on the role of the contracting supplier.

\subsubsection{Cascading contracts}


The first approach is that the public buyer could seek to use the procurement process to influence the whole supply chain through the use of 'cascading' contract performance clauses in which suppliers at each level assume responsibilities with regard to working conditions and workers' rights, monitoring and supervision of the supplier with whom they are in a direct contractual relationship. This passes a chain of contract performance conditions regarding workers' rights and working conditions down the supply chain.

In this approach, the contract between the public buyer and the contracting supplier includes a clause requiring specified conditions to be written into the contracts at every level of the supply chain. In this way the buyer will have determined the conditions to be met by subcontractors further down the chain even though they are not in a contractual relationship with those subcontractors. Each party down the chain would be obliged to ensure that it only entered into contracts with sub-contractors who also agreed to incorporate those conditions, and so on down the chain. Failure to ensure that the agreed contract performance criteria were passed on would ultimately result in a failure of the contractor to fulfil their own contract.

This approach is initially attractive insofar as it provides a legal, contractual basis for the adoption of desired standards at all levels of the supply chain and at the same time works around the problems of an absence of direct legal relationships between the public buyer and suppliers further along the chain and of the public buyer otherwise having to assume an undesirable and disproportionate degree of responsibility for failures by those suppliers.

There are however a number of difficulties with the approach. First, many contracting suppliers and secondary suppliers will already have long-term supply contracts in place and any such clauses would therefore require them to renegotiate a vast number of existing contracts. This would be problematic and impractical because of the need to vary the contracts all the way down the supply chain. In addition, because of the separate nature of the contracts at each stage it would be difficult to check that implementation, in the sense of adoption of the specific clauses throughout the chain, has been achieved all the way through the supply chain. Enforcement and monitoring would in turn be extremely difficult. In any case, in this approach the public buyer is still not in a contractual relationship with subcontractors down the supply chain and can only take action against the contracting supplier at the very top of the chain. The public buyer is not a party to the subsequent contracts and a failure to adopt the specific clauses by parties along the supply chain cannot be enforced by the contracting authority. Although there may be a failure by the contracting supplier to meet the contract conditions (difficulties with implementation and monitoring aside) the impact of this can only extend to action against that supplier and does not enable the public buyer to take or require direct action to remedy the problem that has actually arisen, for example with working conditions, at another point in the supply chain. Therefore, while possible theoretically, this approach might lack the enforceability and practicability necessary to achieve the desired change in standards and conditions.

\subsubsection{Contracting supplier responsibility and supply chain due diligence}

A second, alternative, approach would aim to make the contracting supplier (the one the public buyer has a direct legal relationship with through the procurement contract) assume the main responsibility for ultimately transforming working conditions in the supply chain. 
The first way that this could be achieved is by establishing explicit legal obligations on the supplier to ensure that specified conditions are met by all of the subcontractors in the chain to ensure respect for human rights in their factories (for instance concerning working conditions). This imposes significant, and inflexible, obligations on the supplier since a failure for these obligations to be applied at any point along the supply chain will result in the contracting supplier being in breach of its contract with the public buyer. It would also be very onerous for the public buyer who would need to follow up on the obligations along the supply chain in order to determine compliance by the contracting supplier. It is unlikely that any supplier would be prepared to contract with a public buyer on the basis that they would be in breach of that contract for violations of working conditions by sub-contracted manufacturers further down the supply chain. Although a strictly legalistic option has the benefit of certainty, a more flexible strategy may be preferable in terms of both the burden imposed on the parties and in achieving the desired outcomes.

The second way that a contracting supplier could be made responsible under a procurement contract is that the supplier assumes an obligation to exercise due diligence over its supply chain rather than assuming liability for ensuring that strict outcomes are achieved at levels of the chain. This might overcome the difficulties with the strictly formal, legalistic approach. A due diligence approach would be consistent with current international developments regarding management of supply chains and relations between business partners and subcontractors. In the last decade corporate due diligence has emerged as the main measure of the responsibility of businesses with regard to their impact in human rights. ${ }^{82}$ The UN Special Representative favoured due diligence in its 2008 report establishing the Framework "Protect, Respect and Remedy" ${ }^{83}$ and it is currently the cornerstone of the so called "responsibility to respect" developed in the UN Guiding Principles on Business and Human Rights. ${ }^{84}$ The Guiding Principles identify the responsibilities of business enterprises as including 'a due-diligence process to identify, prevent, mitigate and account for how they address their impact on human rights. ${ }^{185}$ In the sphere of human rights, businesses are expected to 'base their activities on the exercise of due diligence and have in place the processes and mechanisms to track, monitor and respond to any negative human rights impact their activities create'. ${ }^{86}$ Equally, the revised 2011 OECD Guidelines on Multinational Enterprises give a prominent role to corporate due diligence when defining business responsibility to respect human rights. ${ }^{87}$ Whilst the UN Guiding Principles include the need for business to engage in remediation processes for victims of human rights abuses as part of their due diligence, other instruments, including the OECD Guidelines, have been more timid. ${ }^{88}$ The corporate human rights due diligence approach therefore assumes an active role on the part of businesses in identifying, preventing and mitigating, and on some occasions remediating, their impacts on human rights.

A due diligence approach is currently being demanded of business in different spheres and, particularly for the regulation of supply chains. Perhaps the most prominent development has been Section 1502 of the US Dodd Frank Act. ${ }^{89}$ Recognising the link between the exploitation and trade of conflict minerals originating in the Democratic Republic of the Congo and the conflict in that region including extreme levels of violence, particularly sexual and gender-based violence, the Act establishes requirements for disclosure and reporting including the adoption of appropriate due diligence measures. The requirements apply to companies which use specific metals (tin, tantalum, tungsten and gold) for the manufacture of their products. Under section 1502 businesses are required to report on the measures taken to 
exercise due diligence 'on the source and chain of custody of such minerals' in order to avoid the financing of illegal armed groups through their commercial activities. Section 1502 is widely understood to have transformed the approach towards raw materials in the minerals supply chain. In addition, the impact of Section 1502 has accelerated intergovernmental responses to this problem, in the framework of the OECD and the Intergovernmental Conference of the Great Lakes Region. ${ }^{90}$ The approach adopted in this piece of legislation reflects the responsibilities established in the Guiding Principles and requires the company to take an active role in understanding the source of their minerals, performing due diligence and making disclosures. The standard of corporate due diligence with regard to human rights adopted for the implementation of Section 1502, and other national and intergovernmental initiatives dealing with conflict minerals, has been the one defined by the OECD in its Due Diligence Guidance for Responsible Supply Chains of Minerals from Conflict-Affected and High-Risk Areas. This document envisages that in exercising due diligence businesses entities will identify and assess the factual circumstances of their mineral extraction and the associated human rights and conflict risks and will take steps to prevent or mitigate harm, monitor such efforts and report on them. ${ }^{91}$

Although not expressly referring to due diligence, the California Transparency and Supply Chain Act imposes similar requirements and responsibilities. The Act requires retail sellers and manufacturers (whose gross annual worldwide income exceeds one hundred million dollars) to disclose their efforts to eradicate slavery and human trafficking from their direct supply chains. ${ }^{92}$ The disclosure requirement compels the retail sellers and manufacturers to: evaluate risks of human trafficking and slavery in their supply chain; address such risks, audit its suppliers to assess their compliance with company standards for trafficking and slavery in supply chains; require direct suppliers to certify that materials incorporated into their products comply with local laws regarding slavery and human trafficking; maintain internal accountability standards and procedures for employees or contractors failing to meet such standards, and finally; provide training on human trafficking and slavery, particularly on how to mitigate risks, to company employees and management with direct responsibility for supply chain management. ${ }^{93}$ Retail sellers and manufactures need to specify whether the verification was concluded by independent third parties and whether audits were unannounced. Similarly to the Dodd-Frank provision, the Act requires that this information is made publicly available on the company website, which makes companies, potentially, more socially accountable. ${ }^{94}$

Returning to public procurement and the electronics industry supply chain, in this context the contracting supplier would be required by the public buyer in the contract performance conditions to exercise due diligence. The contracting supplier would need to take the necessary steps to identify its own supply chain, and monitor it. It should adopt the necessary measures to avoid abusive labour relationships and practices inconsistent with agreed rights and working conditions. Among the responsibilities of the contracting suppliers would also be independently auditing progress and supply chain conditions and reporting measures taken to comply with the agreed standards and potentially engage in remediation when conditions have been violated This due diligence approach clearly imposes a substantial duty on the contracting supplier but potentially provides for mitigation and improvement on a responsive basis rather than depending on 'all or nothing' compliance. For the public buyer it potentially addresses some of the difficulties arising from the chain of contracts and lack of direct legal relations between the various parties along the chain whilst still providing a means to require that agreed conditions and rights are respected. 


\subsection{Building human rights and social considerations into contract performance conditions}

\subsubsection{Supply chain disclosure: Suppliers and factory locations}

An essential starting point for the incorporation to minimum standards for the protection of workers' rights is to achieve transparency of the supply chain. Only by understanding the supply chain and identifying the factories involved in the manufacturing process can knowledge of the working conditions in those factories involved surface. In a simple contract between a public buyer and a supplier there is no legal requirement for the identification of the sub-contractors which the contractor will use in order to deliver the contracted goods and by extension there is no way to identify where such goods will be manufactured. This gap in information consequently is a significant, initial block to ensuring that workers' rights are respected throughout the supply chain. The identification and disclosure of these subcontractors could therefore be an important condition to impose on the contracting supplier.

One means of achieving the required disclosure would be to introduce a requirement which would cascade through the chain of contracts, in other words each supplier would identify its own suppliers to the respective purchasers up the chain and would pass down that same requirement to its own subcontractors. In and of itself this incorporation of a disclosure requirement into contracts is a relatively simple approach, which is unlikely to be particularly onerous at any stage of the supply chain. An obstacle to the approach though is that many contracted suppliers and secondary suppliers will already have long-term supply contracts in place. As noted above, renegotiating and varying the terms in a large number of contracts is problematic. Issues of confidentiality may also arise in certain contracts. In addition, verification would be complex; because of the separate nature of the contracts at each stage it would be difficult to check that implementation, in the sense of adoption of the disclosure requirement and the necessary means to comply with it, has been achieved all the way through the supply chain.

Alternatively, a due diligence approach could see the contracting supplier assume responsibility for the disclosure of all subcontractors to the public buyer. Here, the public buyer would include in the contract a requirement that the contracting supplier exercises supply chain due diligence, this is, takes all the appropriate measures to trace the supply chain and provide information on all of the subcontractors and factories that form part of the supply chain for the contracted goods. The contracting supplier would assume a responsibility, derived from the contract performance conditions, to work with its contractors and subcontractors to find out the location of all factories in the supply chain and then to disclose these details to the public buyer.

This approach would not only simplify the identification process, ensuring that all factories and suppliers were disclosed at a single point, but would also increase the visibility of the whole supply chain to the public buyer since all subcontractors and manufacturers would be identified directly to them. Although the simplicity of this exercise would benefit the public buyer by reducing the difficulties with ensuring implementation associated with multiple contracts, it would clearly involve a significant undertaking on the part of the supplier. 
Compiling the information would be an expensive, technical and time consuming task for the supplier, which would increase the cost of doing business with a public buyer. External expertise, for instance in the form of a supply-chain due diligence consultancy, may be needed. In light of this, such a requirement is likely to be met with a degree of resistance. ${ }^{95}$ If adopted however, there would be an incentive for suppliers to adopt disclosure requirements in their own contracts which would then reduce the burden over time, as contracts are signed or renewed, and would ensure that the obligation becomes built in along the supply chain.

\subsubsection{Workers' rights and labour standards}

Having provided for disclosure of the supply chain it is necessary to consider the workers' rights and labour standards that would be expected within the identified factories. This involves choices about what the standards are and how, or by whom, those standards are determined. In this respect the choice of approach (through clauses in every contract or via due diligence of the contracting supplier) has less relevance than for other aspects of the model because the agreed standards can in theory be adopted in either approach.

In determining what the appropriate labour standards should be, one option is to start with the problem itself, for instance, lead times for the delivery of goods that are too short or wages that are too low. In this case an agreement might include requirements for 'reasonable' or 'fair' lead times and pay. This approach is problematic from the point of view of contractual relations and enforcement. Because terms such as 'reasonable lead times' or 'fair wages' are wide and imprecise it is unlikely that contracting parties would be willing to sign contracts in which they were used and even if they were willing, such terms might invite problems and litigation where parties disagreed as to their meaning. A preferable approach is to address the working conditions upon which the problems rest, for instance by determining requirements for minimum wages, maximum working hours, and security of employment contracts. Such terms are preferable from a contractual point of view because they are precise which means that parties are more likely to be willing to agree to their inclusion and that they are also more easily enforceable.

As to the specific labour standards to be applied, one means of determining these is by reference to existing external standards. A logical point of reference is the concept of decent work developed by the ILO. ${ }^{96}$ A reference to these will have the advantages of clarity and a strong grounding in international standards. Reference to international social standards is, as discussed, also made in the EU Directives, including to the core ILO Conventions, giving further weight to their use. As discussed one limitation is that the ILO Conventions do not address all factors relevant to problems in the electronics supply chain. If the buyer wishes to address additional concerns associated with the electronics supply chain it may be necessary to supplement these for instance with reference to minimum wages.

Another option would be to have the standards determined by an external organisation. This approach has been adopted in initiatives in other sectors. The Workers' Rights Consortium (WRC) for instance, works with university and college members to improve conditions for workers in the apparel supply chain. The model is based on adoption of a Code of Conduct by affiliate members that sets out expectations of members including standards to be required of their suppliers. ${ }^{97}$ Likewise, the Fair Labor Association (FLA) works with affiliated companies who agree to adopt FLA's Workplace Code of Conduct. ${ }^{98}$ This option 
would require the contracting supplier to agree to ensure that all of its subcontractors allow the independent organisation access to their factories for the purpose of monitoring (see below). Full, clear details as to what standards would be expected would necessarily have to be established in advance of the supplier and subcontractors agreeing to adopt this condition, as they are unlikely to agree to conditional clauses or requirements which would leave the determination of responsibilities and duties vague.

\subsubsection{Monitoring conditions and gaining access to the factories}

Ensuring that agreed labour standards are being adhered to within the supply chain requires independent monitoring systems, which in turn is only possible if there are provisions for accessing the site and factories involved for the purpose of such verification or monitoring. The main issue is which party assumes the responsibility for such monitoring. A public buyer is highly unlikely to have the resources to undertake this role even if it did have a willingness to take on this burden. Equally, the contracting supplier may not have the means or willingness to undertake such monitoring, and leaving it to each contractor raises questions of independence. This is where independent organisations acting in a monitoring or auditing role have a role to play. Organisations acting in this role exist in other industries. The WRC, for instance, carries out investigations of factories producing apparel for sale in the USA and Canada, makes recommendations for remediation in the event that violations are identified and works with US apparel companies to encourage implementation of those recommendations. Similarly, FLA carries out monitoring and assessments to determine compliance and makes recommendations where problems are identified. ${ }^{99}$ The Sweatfree Purchasing Consortium referred to above is also based on the involvement of an independent monitoring body. Independent monitoring to verify conditions in the supply chain is also the model adopted by Electronics Watch, who plans to work alongside workers and local civil-society organisations in these investigations. ${ }^{100}$

The main issue with regard to using independent monitoring organisations to verify the compliance with the agreed labour standards in the supply chain is how to legally compel the members of the chain to engage with such monitoring schemes and provide access to their factories. Within an ordinary contract between the buyer and supplier introducing a monitoring mechanism is again problematic because the buyer is not in a contractual relationship with the subcontractors down the supply chain and therefore cannot enforce the requirement for access. A condition that access by an independent monitoring organisation be included in its own contracts could be applied to the supplier but again, depending on the supply chain, some subcontractors might not be in a contractual relationship with the supplier.

In the cascading contractual clauses approach, every contract would have to include a monitoring clause demanding each subcontractor to join the monitoring scheme and have a direct relationship with the monitoring organisation. This approach is problematic because the public buyer would be reliant on the supplier or subcontractor enforcing the conditions in their own contract; the buyer will not have a clear means of ensuring that the requirement for access has been adopted.

A supplier due diligence approach might offer the more pragmatic solution. In this approach the supplier, taking action to prevent or mitigate abuses of working conditions in its supply chain, would assume responsibility for ensuring that all the companies in its supply 
chain agree to allow access by an independent monitoring organisation. This responsibility would be identified in the contract performance conditions but, in line with the due diligence approach, decisions as to how it is achieved would be made by the contracting supplier. A supplier might, for instance, decide to incorporate this responsibility contractually, incorporating the requirement into its contracts with sub-contractors and manufacturers as they are signed or renewed. Alternatively a less formal approach (i.e. one based on voluntary agreements) might be pursued. The contract performance conditions could potentially incorporate a requirement that the contracting supplier regularly report on the action it has taken to discharge these responsibilities.

Again a large degree of responsibility here lies with the contracting supplier rather than the public buyer but it does provide an opportunity for the buyer to ensure that the all relevant levels of the supply chain adopt the requirement for access and monitoring. Although this arrangement is burdensome for the supplier in some respects it could also be the case that once a supply chain for a product has been fully reported on and subject to monitoring or auditing this would be an asset to the supplier, since the product would then be more attractive to public sector bodies who are seeking assurances about workers' rights and social responsibility in the supply chain.

\subsubsection{Remediation, penalties and sanctions}

The options discussed above assume a model in which the public buyer adopts contract performance conditions with the aim of ensuring that the electronic goods that it is procuring come from a supply chain in which workers' rights are respected. An important consideration in this process is the consequences that should flow in the event of non-compliance by any of the parties.

In earlier stages of the process outlined above the contracting supplier has taken steps to identify and prevent human rights violations or poor working conditions by understanding and disclosing the supply chain and introducing an independent monitoring process through that chain. In line with its further responsibility to mitigate or redress harm the contracting supplier should also be required to act when non-compliance and supply chain problems are identified. Where an independent organisation performs a role in monitoring supply chain factories it is logical that they would report violations of the determined standards to the supplier. The terms and definitions of these violations would need to be clearly specified. The contracting supplier would then assume responsibility for acting in response to violations.

In line with the most demanding approach to corporate due diligence (as defined by the UN Guiding Principles) mechanisms for remediation will be needed. Such mechanisms should ideally provide a means by which all relevant parties (including supply chain employees, sub-contractors, the contracting supplier, and the public buyer) can raise issues and seek resolution and remedies. These remediation processes may be mediated by independent monitoring organisations or directly managed by the contracting supplier as long as they provide the necessary assurance of independence. Whether deriving from a remediation process or not sanctions and penalties for non-compliance with the required working conditions will need to be defined. The choice of sanction or penalty may depend on factors such as the degree or persistence of the violation and the desired outcome (for instance whether the sanction seeks to encourage compliance or create a deterrent effect). Sanctions such as 
termination of a contract or blacklisting may have an immediate effect in enabling the supplier to work with a new subcontractor and acting as a strong deterrent but may also heavily penalise workers at the factory (for example though unemployment) and might not lead to improved standards particularly where the factory is producing goods or components under contract to other suppliers and can continue to operate on that basis. In some situations a more cooperative approach based on working with the monitoring organisation to remedy and raise standards, within an agreed framework, might be preferable if there is a reluctance to penalise the factory owners and their employees.

\section{Conclusion}

Ensuring that adequate human rights and labour standards are respected in the electronics supply chain is a pressing concern because of the significant size of the sector and its manufacturing operations and the implications of failings in this chain, as highlighted by the recent scandals described in the introduction. . Public buyers are significant consumers of electronic products and thus public procurement is a potentially powerful tool to create demand for improved supply chain conditions. However, to date the full potential has been exploited only in very limited circumstances. Our analysis of the incoming EU Directive suggests that the potential to address supply chain issues, as social criteria, appears expanded but remains limited. Although the new Directive aimed, among other things, to clarify the scope for inclusion of social criteria in public procurement, it falls short of introducing a clear and broad opportunity to do so. Particular obstacles include a lack of clarity of the interpretation of the subject-matter requirement and the need to pursue the most economically advantageous tender. To the extent that social considerations are referred to the emphasis - as with earlier attempts to pursue 'horizontal policies' - appears to lie with domestic concerns and not with extraterritorial, supply chain matters.

Within the sometimes unclear and limited framework of the EU legal regime for public procurement the stage in which contract performance conditions are being included in the procurement contract (rather than in the technical specifications or award criteria) provides the greatest opportunity to influence supply chain conditions. This article has therefore considered how contract performance considerations could be employed by public buyers to address workers' rights in the electronics supply chain. An approach based on cascading contract terms, adopted and demanded at each level of the supply chain, provides for certainty and can be enforced in the same way as any other contract terms. This approach though is impractical to incorporate and is likely to act as a disincentive to potential contractors and sub-contractors. Alternatively an approach based around principles of corporate due diligence could provide a more pragmatic and responsive strategy, ultimately leading to greater improvements in the supply chain. In discussing how social considerations - specifically labour rights - could be incorporated into contract performance, we focused on the means by which the supply chain could be identified, standards determined and improvements or failings identified, recognised and responded to. Certainly, whilst the drive to improve standards can come from the public buyer it is unrealistic to assume that these buyers would take on responsibility for establishing standards and carrying out activities to monitor compliance along the supply chain. At the same time it may also be very onerous on the contracting supplier to undertake compliance monitoring throughout its supply chain. A model based on working with an independent monitoring organisation could address this outstanding need and has been seen in other models such as the Sweatfree Purchasing Consortium. 
The EU rules potentially provide some legal scope to pursue improved working conditions in the electronics industry through public procurement. Exploiting this potential will require demand from public buyers as well as a willingness on the part of contractors and supply chain companies to work collaboratively and assume greater responsibility. While challenging, the burden on each party would be significantly reduced over time, as requirements become established. Incorporating this approach might then be beneficial to contractors (and their sub-contractors down the chain) seeking to tender for the supply of electronic goods to public buyers. Clearly, utilising the potential of public procurement depends to an extent on taxpayer support for public funds to be spent in socially responsible ways, and thus public awareness is likely also to be crucial to implementation. However, working with options to incorporate transparency, human rights, labour standards, and independent monitoring there are limited but specific opportunities within the legal framework for public procurement for public buyers to seek to improve working conditions in the electronics supply chain by leveraging their buying power. 
Notes 
${ }^{1}$ See for instance BBC News, "Ninth worker death at Taiwan iPhone firm Foxconn”, 21 May 2010, available at http://www.bbc.co.uk/news/10137101.

${ }^{2}$ See for instance Duhigg, C. \& Barboza, D., 'In China, Human Costs Are Built Into an iPad', New

York Times, 25 January 2012, available at http://www.nytimes.com/2012/01/26/business/ieconomyapples-ipad-and-the-human-costs-for-workers-in-china.html?pagewanted=all\&_r=1\&; and Barboza, D., 'Worker Deaths Raise Questions at an Apple Contractor in China', New York Times, 10 December 2013, available at http://www.nytimes.com/2013/12/11/technology/worker-deaths-raise-questions-atan-apple-contractor-in-china.html and the BBC's Panorama program “Apple’s Broken Promises”, first broadcasted December 2014, http://www.bbc.co.uk/programmes/b04vs348.

${ }^{3}$ See for instance Interbrand 'Best Global Brands 2013', available at http://www.interbrand.com/en/best-global-brands/2013/Best-Global-Brands-2013.aspx. In this report the top 10 companies include Apple Inc., Google, IBM, Microsoft, Samsung and Intel.

${ }^{4}$ See for instance CNN, 'Fortune Global 500: The most profitable companies in the Global 500', 8 July 2013, available at http://money.cnn.com/gallery/magazines/fortune/2013/07/08/global-500-mostprofitable.fortune/2.html. In this report Apple Inc. are ranked 2nd and Samsung Electronics ranked the 12th most profitable companies in the world.

${ }^{5}$ See OECD, 'Mapping Global Value Chains', Report TAD/TC/WP/RD(2012)9, 3 December 2012: 27-29. The report notes that 'standardisation, codification and computerisation allow for a large interoperability of parts and components which in turn allows for the fragmentation of the production process across different stages.'

${ }^{6}$ Sturgeon, T.J., \& Kawakami, M., 'Global Value Chains in the Electronics Industry: Was the Crisis a Window of Opportunity for Developing Countries?', The World Bank, Policy Research Working Paper 5417, September 2010: 3.

${ }^{7}$ OECD, 2012: 28

${ }^{8}$ Good Electronics, 'Reset. Corporate social responsibility in the global electronics supply chain', October 2009: 19.

${ }^{9}$ Sturgeon \& Kawakami, 2010: 4-5

${ }^{10}$ Decision, 'World Electronic Industries 2008-2013', April 2009: 14, available at http://www.decision.eu/doc/brochures/exec_wei_current.pdf.

${ }^{11}$ Good Electronics, 2009: 19

${ }^{12}$ Independent research bodies, NGOs and collaborative campaigning initiatives in particular have published several reports highlighting these issues. See for instance: DanWatch, 'IT workers still pay the price for cheap computers', 2013; Ferus-Comelo, A., \& Pöyhönen, P., 'Phony Equality', Make IT Fair, 2011; Kakuli, A. \& Schipper, I., 'Out of Focus: Labour rights in Vietnam’s digital camera factories', Make IT Fair, 2011; Chan, J., \& Ho, C., 'The Dark Side of Cyberspace', World Economy, Ecology and Development (WEED), 2008; and China Labor Watch, 'An Investigation of Eight Samsung Factories in China: Is Samsung Infringing Upon Apple’s Patent to Bully Workers?’, 2012. ${ }^{13}$ See note 1.

${ }^{14}$ See Kakuli \& Schipper, 2011. The ILO has established eight 'fundamental conventions', these are Freedom of Association and Protection of the Right to Organise Convention, 1948 (No. 87); Right to Organise and Collective Bargaining Convention, 1949 (No. 98); Forced Labour Convention, 1930 (No. 29); Abolition of Forced Labour Convention, 1957 (No. 105); Minimum Age Convention, 1973 (No. 138); Worst Forms of Child Labour Convention, 1999 (No. 182); Equal Remuneration Convention, 1951 (No. 100); Discrimination (Employment and Occupation) Convention, 1958 (No. 111). A further four conventions have been designated as priority instruments; these are recognised in the ILO Declaration on Social Justice for a Fair Globalization (2008) as the most significant with respect to governance. The priority conventions are Labour Inspection Convention, 1947 (No. 81); Employment Policy Convention, 1964 (No. 122); Labour Inspection (Agriculture) Convention, 1969 (No. 129); Tripartite Consultation (International Labour Standards) Convention, 1976 (No. 14).

${ }^{15}$ Chan \& Ho, 2008

${ }^{16}$ Ferus-Comelo \& Pöyhönen, 2011

${ }^{17}$ Chan \& Ho, 2008; China Labor Watch, 2012

${ }^{18}$ Kakuli \& Schipper, 2011; China Labor Watch, 2012

${ }^{19}$ Pringle, T., 'Reflections on Labor in China: From a Moment to a Movement', South Atlantic

Quarterly, 112:1, 2013

${ }^{20}$ Pringle, 2013

${ }^{21}$ Ferus--Comelo \& Pöyhönen, 2011

${ }^{22}$ Ngai, P., \& Chan, J., 'Global Capital, the State, and Chinese Workers: The Foxconn Experience', Modern China, 38, 383 
${ }^{23}$ Chan \& Ho, 2008

${ }^{24}$ Kakuli \& Schipper, 2011

${ }^{25}$ Ferus--Comelo \& Pöyhönen, 2011Kakuli \& Schipper, 2011Chan \& Ho, 2008

${ }^{26}$ China Labor Watch, 2012

${ }^{27}$ Chan \& Ho, 2008; China Labor Watch, 2012

${ }^{28}$ Chan \& Ho, 2008; Kakuli \& Schipper, 2011

${ }^{29}$ Chan, A., 'Organising Wal-Mart in China: Two Steps Forward, One Step Back for China's Unions'. New Labor Forum, 16:2, 2007: 86--96; Chan \& Ho, 2008; Ferus-Comelo \& Pöyhönen, 2011

${ }^{30}$ According to the consultants $\mathrm{PwC}$, worldwide combined shipments of consumer electronics devices are projected to reach 2.5 billion units in 2014, a 7.6\% increase from 2013. Report available at http://www.pwc.com/gx/en/technology/scorecard/consumer--electronics.jhtml

${ }^{31}$ See discussion of due diligence below.

${ }^{32}$ de Hann, E., \& Schipper, I., 'Computer Connections. Supply chain policies and practices of seven computer companies', SOMO, 2009

${ }^{33}$ The EICC Code of Conduct is available at http://www.eicc.info/eicc_code.shtml

${ }^{34}$ As noted on the EICC website, available at http://www.eicc.info/about_us05.shtml

${ }^{35}$ For discussion of compliance with the EICC Code by the electronics brand HP see Locke, R., Distelhorst, G., Pal, T., \& Samel, H., 'Production Goes Global, Standards Stay Local: Private Labor Regulation in the Global Electronics Industry', Massachusetts Institute of Technology, Working Paper No 2012-1, 2012: 10.

${ }^{36}$ See further GeSI (the Global e-Sustainability Initiative) at http://gesi.org/

${ }^{37}$ Electronics Watch brings together a coalition of international non--governmental organisations, European public buyers, local monitoring organisations and trade unions. The initiative was launched in early 2014 and is expected to be fully functioning by mid--2015. For further information see http://electronicswatch.org/en.

${ }^{38}$ Chan \& Ho, 2008; Kakuli \& Schipper, 2011

${ }^{39}$ Howe, 2010: 3

${ }^{40}$ Howe, 2010: 2

${ }^{41}$ As noted on the European Commission, DG Trade website 'Public Procurement in a Nutshell' available at http://ec.europa.eu/trade/policy/accessing--markets/public--procurement/

42 OECD, 'Size of Public Procurement Market', in Government at a Glance 2011, 2011: 148

${ }^{43}$ European Commission, DG Trade website 'Public Procurement in a Nutshell'

${ }^{44}$ See Chan \& Ho, 2008: 28

${ }^{45}$ See Howe, 2010 and World Economy, Ecology and Development (WEED), 'Buy It Fair. Guidance for Sustainable Procurement of Computers', 2009, available at http://makeitfair.org/en/procure--it-fair/procure--it--fair--buyers--guides--available--in--seven--languages

${ }^{46}$ Arnaiz, T.M., 'Social considerations in Spanish public procurement law', Public Procurement Law Review, 2011: 56

${ }^{47}$ Leire, C., \& Mont, O., 'The Implementation of Socially Responsible Purchasing', Corporate Social Responsibility and Environmental Management 17, 27--39, 2010

${ }^{48}$ See McCrudden, C., 'Using public procurement to achieve social outcomes', Natural Resources Forum 28, 2004: 257-267; and see Howe, 2010.

${ }^{49}$ See Howe, 2010: 18

${ }^{50}$ For further information see the Consortium's website at http://www.sweatfree.org/about_us

${ }^{51}$ See The Sweatfree Purchasing Guide, Version 1, USA, May 2011 available at http://buysweatfree.org/files/guide_to_sweatfree_procurement.pdf

${ }^{52}$ See http://buysweatfree.org/members

${ }^{53}$ See further Howe, 2010.

${ }^{54}$ Client Earth, 'Identifying Opportunities for Sustainable Public Procurement, Briefing No. 7: Award Criteria’ Legal Briefing Series, Award Criteria, October 2011: 3.

${ }^{55}$ See European Commission, Green Paper on 'Public procurement in the European Union: exploring the way forward', Green Paper, COM (96) 583 final, 1996 final; and European Commission, 'Interpretative Communication of the Commission on the Community law applicable to public procurement and the possibilities for integrating social considerations into public procurement', COM (2001) 566 final, 2001. See also the ECJ rulings: Gebroeders Beentjes BV v State of the Netherlands (31/87) [1988] E.C.R. I-4635; Du Pont de Nemours Italiana SpA v Unità sanitaria locale $N^{\circ} 2$ di Carrara (C-21/88) [1990] E.C.R. I-889; [1991] 3 C.M.L.R. 25; and Laboratori Bruneau Srl v Unità sanitaria locale RM/24 di Monterotondo (C-351/88) [1991] E.C.R. I-3641; [1994] 1 C.M.L.R. 707. ${ }^{56}$ McCrudden, 2004 
${ }^{57}$ Agreement on Public Procurement (GAP), 1994, entered into force on 1 January 1996. The GPA is one of the plurilateral agreements included in Annex 4 to the Marrakesh Agreement Establishing the WTO. This means only those WTO Members who are a party to the Agreement are bound by its obligations and responsibilities. The EU is a party to the Agreement.

${ }^{58}$ Article III, GPA and see Articles IV, V and preamble.

${ }^{59}$ Directive 2004/18/EC of the European Parliament and of the Council of 31 March 2004 on the coordination of procedures for the award of public works contracts, public supply; Directive 2004/17/EC of the European Parliament and of the Council of 31 March 2004 coordinating the procurement procedures of entities operating in the water, energy, transport and postal services sectors, contracts and public service contracts.

${ }^{60}$ Directive 2014/24/EU of the European Parliament and of the Council or 26 February 2014 on public procurement and repealing Directive 2004/18/EC

${ }^{61}$ Impact Assessment Accompanying the Proposal for a Directive of the European Parliament and of the Council on Public Procurement, SEC(2011) 1585 final, Brussels, 20.12.2011 at 23

${ }^{62}$ The financial thresholds at which procurement rules apply are slightly lower for central government bodies than for other public sector bodies and slightly higher for supply and service contracts. Art 4 of Directive 2014/24 establishes the thresholds as $€ 186,000$ for public works contracts, $€ 134000$ for public supply and service contracts awarded by central government authorities or $€ 207000$ for supply and service contracts awarded by sub--central authorities. The lack of regulation of contracts under such thresholds is due to the assumption of the European legislator that tenders of little economic value do not have important effects when stimulating the internal market.

${ }^{63}$ Arnaiz argues that even if a public procurement contract falls outside of the Directives, most public authorities voluntarily act within their provisions. Arnaiz, 2011: 62

${ }^{64}$ European Commission, “'Buying Green: A Handbook on Public Procurement', 2011: 16, available at: http://ec.europa.eu/internal_market/publicprocurement/docs/gpp/buying_green_handbook_en.pdf

${ }^{65}$ Note that although the European Commission identifies value for money as a key principle, Arrowsmith and Kunzlik argue that it is not per se an objective of the European regime, partly on the basis that this is not an objective that is within the competence of the EU. In this argument value for money is a matter for member states as distinct from an internal policy objective of the EU, and EU rules might then be seen to facilitate the pursuit of value for money by member states but is not a general policy aim for the EU. See Arrowsmith, S. and Kunzlik, P., 'Public procurement and horizontal policies in EC law: general principles' in Arrowsmith \& Kunzlik (eds) Social and Environmental Policies in EC Procurement Law, Cambridge: CUP, 2009; and see further Arrowsmith, 'S. Understanding the purpose of the EU's of the EU regime and some proposals for reform procurement directives: the limited role', in The Cost of Different Goals of Public Procurement, Stockholm: Swedish Competition Authority, 2012.

${ }^{66}$ European Commission, 'Buying Green', 2011: 16.

${ }^{67}$ See Impact Assessment Accompanying the Proposal for a Directive of the European Parliament and of the Council on Public Procurement, SEC(2011) 1585 final, Brussels, 20.12.2011 at 23

${ }^{68}$ Client Earth, 'Identifying Opportunities for Sustainable Public Procurement, Briefing No. 7: Award Criteria’ Legal Briefing Series, Award Criteria, October 2011: 3.

${ }^{69}$ Annex VII (1). Climate change performance has been the only new addition in 2014.

${ }^{70}$ This restrictive interpretation is reinforced by the Explanatory Memorandum which accompanied the proposed version of the new Directive which, when reviewing the new considerations regarding production processes, explicitly excludes requirements not related to the process of producing the product. The Memorandum, at p. 10, reads as follows: 'Contracting authorities may refer to all factors directly linked to the production process in the technical specifications and in the award criteria, as long as they refer to aspects of the production process which are closely related to the specific production or provision of the good or service purchased. This excludes requirements not related to the process of producing the products, works or services covered by the procurement, such as general corporate social responsibility requirements covering the whole operation of the contractor.'

${ }^{71}$ Article 43(1) refers to the possibility of contracting authorities laying down environmental, social or other characteristics and requiring the use of labels related to these criteria. This may only apply however, where specified conditions are met including that they are related to the subject matter. ${ }^{72}$ The explanatory memorandum to the proposals for Directive 2014/24 also refers to the possibility of including social considerations in labels but is not clear as to how these might relate to the subjectmatter of the contract: 'Contracting authorities may require that works, supplies or services bear specific labels certifying environmental, social or other characteristics, provided that they accept also equivalent labels. This applies for instance to European or (multi-)national eco-labels or labels certifying that a product is free of child-labour. The certification schemes in question must concern 
characteristics linked to the subject-matter of the contract and be drawn up on the basis of scientific information, established in an open and transparent procedure and accessible to all interested parties'. It should be noted that this Memorandum does not form part of the final proposals - it merely provides background information. Its relevance may be in aiding interpretation by the Courts.

${ }^{73}$ Article 53, 2004 Directive.

${ }^{74}$ See also Recital 98 and 99.

${ }^{75}$ And see Explanatory Memorandum accompanying Proposed Directive, p. 10.

${ }^{76}$ Recital 33 of the Preamble and Article 26. See also Buying Social, 2010. An example given here is that for the building of a school, accessibility could be part of the subject--matter of the contract whereas the labour conditions of those employed to build the school could not since these conditions do not relate to the object of the contract. However, those labour conditions could be incorporated into the contract performance conditions. Here they would relate to the execution of the contract.

${ }^{77}$ The only reference to working conditions in Directive 2004/18 is art. 27 which establishes that contracting authorities may state in the contract documents, or be obliged by a Member State so to state, the body or bodies from which a candidate or tenderer may obtain the appropriate information on the obligations relating to taxes, to environmental protection, to the employment protection provisions and to the working conditions which are in force in the Member State, region or locality in which the works are to be carried out or services are to be provided and which shall be applicable to the works carried out on site or to the services provided during the performance of the contract. This clause seem to refer exclusively to work carried out in EU Member States, therefore would not be relevant when considered working conditions in the global supply chain of electronics.

${ }^{78}$ Chapter IV as a whole deals with contract performance.

${ }^{79}$ For ILO Conventions and Recommendations see http://ilo.org/global/standards/introduction-tointernational-labour-standards/conventions--and-recommendations/lang--en/index.htm

${ }^{80}$ Recital 105.

${ }^{81}$ See European Commission, Public Procurement Reform, Fact Sheet No 8: Social Aspects of the New Rules (undated), available at

http://ec.europa.eu/internal_market/publicprocurement/docs/modernising_rules/reform/fact-sheets/factsheet-08-social_en.pdf. This explains, as regard the social criteria, that when considering how the goods they intend to purchase are produced, public buyers may 'decide to award the contract concerned to the company that intends to employ the greatest number of disadvantaged people, such as the longterm unemployed'. They may also consider the working conditions of the employees involved in production of the goods specifically covered in the procurement contract but cannot be required to apply a general social or environmental responsibility policy, as such a requirement is not specific to the goods or services purchased.

${ }^{82}$ Martin-Ortega, O., 'Human Rights Due Diligence for Corporations: form Voluntary Standards to Hard Law at Last?’, Netherlands Quarterly of Human Rights, 32, 2014: 49-50; see as well,

McCorquodale, R., 'Corporate Social Responsibility and International Human Rights Law', Journal of Business Ethics, 87, 2009: 392

${ }^{83}$ Ruggie, J., 'Report of the Special Representative of the Secretary General on the issue of human rights and transnational corporations and other business enterprises, Guiding Principles on Business and Human Rights: Implementing the United Nations “Protect, Respect and Remedy” Framework', 21 March 2011, A/HRC/17/31

${ }^{84}$ The framework is described as resting on three pillars: the state duty to protect against human rights abuses, corporate responsibility to respect human rights, 'which means that business enterprises should act with due diligence to avoid infringing on the rights of others...' and the need for access by victims to effective remedies. See Ruggie, 2011, at paragraph 6.

${ }^{85}$ Ruggie, 2011, Guiding Principle 15(b)

${ }^{86}$ Martin-Ortega, O. and Wallace, R., Business, Human Rights and Children: the Developing International Agenda, Denning Law Journal, 25, 2013: 105-127

${ }^{87}$ The OECD Guidelines on Multinational Enterprises were first passed in 1976 as part of the Declaration on International Investment and Multinational Enterprises. The current revised version was adopted by the OECD Investment Committee on 25 May 2011. See particularly, Section IV on Human Rights.

${ }^{88}$ When businesses identify that they have caused or contributed to an adverse human rights impact, the Guiding Principles require them to provide for remediation or at least to cooperate in a legitimate remedy procedure (Guiding Principle 22). The OECD Guidelines, on the contrary, only contain references to remediation in its commentary, but not in the main text. The OECD Due Diligence Guidance for Responsible Supply Chains of Minerals from Conflict-Affected and High Risk Areas, 
cited below, does not even make a reference to engagement in remedy procedures among its due diligence steps.

${ }^{89}$ Dodd-Frank Wall Street Reform and Consumer Protection Act, 2010. 124 STAT. 1376

${ }^{90}$ See generally, Martin--Ortega, 2014, for a study of the UN Security Council response to conflict minerals demanding corporate due diligence, the Intergovernmental Conference of the Great Lakes Region's Regional Certification Mechanism and its evolution towards corporate due diligence and national normative responses.

${ }^{91}$ OECD Due Diligence Guidance for Responsible Supply Chains of Minerals from Conflict--Affected and High--Risk Areas, 2nd ed 2013

${ }^{92}$ California Transparency and Supply Chain Act (SB 657). The Act was passed in 2010 and entered into force in January 2012.

${ }^{93}$ Ibid, Section 10(2)(c)(1-5). For further analysis of the Act see Bernaz, N., 'Enhancing Corporate Accountability for Human Rights Violations: Is Extraterritoriality the Magic Potion?', Journal of Business Ethics, 117, 2013: 493-511.

${ }^{94}$ With regard to Section 1502 Ochoa and Keenan have sustained that this provision will mean that other stakeholders, such as civil society organisations, will have access to valuable information to assist their public campaigns or, potentially, to pursue litigation, Christiana Ochoa and Patrick Keenan, 'Regulating Information Flows, Regulating Conflict: An Analysis of the United States Conflict Minerals Legislation', Gottingen Journal of International Law 3 (2011): 134.

${ }^{95}$ Similar due diligence requirements imposed to address conflict minerals, including through the Dodd-Frank Act, have been met with resistance. See for example, Epstein, M., and Yutha, K., 'Conflict minerals: Managing an emerging supply-chain problem ' Environmental Quality Management Volume 21, Issue 2, pages 13-25, Winter 2011

${ }^{96}$ Since 2008 the ILO has been developing Decent Work Indicators for a number of countries. For further information on the Decent Work agenda, see http://www.ilo.org/global/about-the-ilo/decentwork-agenda/lang--en/index.htm. For access to the ILO’s country specific reports on measuring decent work, see http://www.ilo.org/integration/themes/mdw/lang--en/index.htm

${ }^{97}$ For further information on the WRC factory assessment program, see their website at http://www.workersrights.org/Freports/monitoring.asp

${ }^{98}$ For the FLA's Workplace Code of Conduct, see http://www.fairlabor.org/our-work/labor-standards

${ }^{99}$ See the FLA's analogy of their role with medical care, through a check-up, diagnose, remedy, follow-up model, available at http://www.fairlabor.org/our-work/our-methodology.

100 See Electronics Watch: http://electronicswatch.org/en/our-aims_1377 